\title{
Miles That Bind: Commuter Marriage and Family Strengths
}

\author{
Richard Glotzer, Anne Cairns Federlein
}

\begin{abstract}
The socio-economic context leading some families to consider commuter marriage is first detailed in this article. As a means of assessing strengths and vulnerabilities to determine whether commuting is a viable option, the family strengths perspective, in tandem with family counseling, is then offered. The authors' experiences as commuter spouses and parents are presented as case studies, followed by a brief discussion of family dynamics and social and economic mobility.
\end{abstract}

Key Words: marriage, commuting, family strengths, case studies

Richard Glotzer, Ph.D. is Director, School of Family and Consumer Sciences, 215C Schrank Hall South, The University of Akron, Akron, OH, 44325. Electronic mail may be sent via the Internet to glotzer@uakron.edu.

Anne Cairns Federlein, Ph.D. is President, Kentucky Wesleyan College, 3000 Frederica Street, Owensboro, KY, 42301.

Commuter marriages are characterized by one spouse being resident in the family home, often with work and child-care responsibilities, while the other spouse works and lives away from home for extended periods. This arrangement of family life poses unique challenges for families drawn to the potential benefits of commuting. Commuter marriage entails enormous sacrifices and emotional costs and is not for most families. Still, it may work for others. 
Long distance commuter marriages are growing in number. Organizing marital and family life around the absence of a spouse is becoming a more familiar part of America's social landscape, making this an opportune time to familiarize readers with the literature in this area, while offering two examples of how commuting has worked for the authors' families. The literature on commuter marriage remains fairly thin, despite strong beginnings twenty years ago. Much relevant data draws from the area of Work and Families and from the corporate world.

There are differing motivations for commuting. Commuters having a short or limited time-line for commuting may accept it as part of their occupation, or feel that enduring the short term stress and disruption of commuting may bring long term benefits. These benefits include possible advancement, acquiring new skills, recognition as a loyal "team player", or even the attractiveness of a temporary change in routine or locale. Receiving emotional support and encouragement from friends, family or colleagues, with office work, child care, and home maintenance are also easier to come by when the need is of limited duration. This regimen of commuting is easier to explain to children and negotiate with one's spouse.

Long term commuters may be motivated by other factors. Wanting to stay in one's occupation or profession when work is not readily available is a strong motivator, particularly when work is unavailable locally or available employment involves a lower salary. Leveraging commuting into quality of life issue may be another motivator. For example, commuters working in New York or Boston during the week but live in Up-State New York, Western Massachusetts or rural New England, often stress quality of life issues for their families, noting that their purchasing power is increased by their residential choices. Family relationships surely suffer the emotional and logistical dislocations of long distance commuting yet the commuting spouse remains in a readily accessible regional orbit.

Longer distance open-ended commutes are most difficult. Visits home for the commuting spouse take longer, entail more 
expense, and are of shorter frequency and duration. These types of commuter marriages are hardest on the emotional bonds, routines and intimacy of couples. Such commutes are also hardest on children, pressing one parent into a "super parent role" while the other parent struggles to make their parenting real to their children. Commuters in this category, like regional commuters, tend to have a strong identification with their careers and derive a strong sense of satisfaction from them. The opportunity to work for extended periods on assignments or projects without the interruption of family life is often satisfying to such individuals. Association with professional colleagues and independence in scheduling their time is also a plus, as is personal freedom and "their own" environment. These considerations clash directly with the values associated with being part of a family, and it not surprising that such relationships work best when couples are enjoying an empty nest. The most successful commuters are those that can, like single residence dual career couples, compartmentalize work and family life (Franklin \& Ramage, 1999; Schnittger \& Bird, 1990). Commuters who tend to meld work and family together have the hardest time with commuting. Neither offers much to children or the remaining spouse with the emotional dislocations of commuting.

Little has been written about the composition of the commuting public, and estimates of the number of commuters vary from 700,000, to over a million in the United States alone (Jackson, Brown, \& Patterson-Stewart, 2000). If military families and other occupational groups traditionally involving family separation are factored out, commuters tend to be professionally employed male college educated spouses, with a median income of between $\$ 30,000$ and $\$ 40,000$, with a mean age of 35 . There are commuters at all stages of career and family life. Approximately half are parents and have been married about ten years or longer (Anderson \& Spruill, 1993; Bunker, Zubeck, \& Vanderslice, 1992). Lack of accurate numbers and detailed demographic information reflect the invisibility of commuters. Commuters have no lobbying organization, and despite their growing numbers, are not yet seen as a distinct occupational category. 
This article also draws from the family strengths perspective. Remarkably similar strengths have been identified in families in settings across cultures, social classes, and nationalities. While Family strengths may vary widely in their social expression the universality of the characteristics of strong families is a feature of this perspective

Stinnett and DeFrain (1985), building on the therapy centered work of Otto $(1962,1963)$ constructed a framework of six family strengths: 1) commitment to family; 2) spending time together; 3 ) the ability to cope with stresses and crises; 4) spiritual

well-being; 5) positive communication; and 6) showing appreciation and affection for each other. By emphasizing what is right with families and what works for families rather than how nontraditional modes of organizing family life deviate from a hypothetical norm, family strengths offers robust and objective conceptual tools for examining the integrity of families. Identifying family strengths also affords families the opportunity to better understand their own dynamics, using these strengths as vehicles for furthering growth (Olsen \& DeFrain, 1994). As McCubbin, Thomson and McCubbin, (1996) suggest, strong families often acquire or improve qualities of internal resiliency in the face of challenge, stress and crisis. In offering their reflections on commuting, the authors integrate family strengths with a narrative perspective drawn from Life Course Studies (Leiblich, Tuval-Mashiach, \& Zilber, 1998).

\section{Commuter Marriage}

The seminal research on commuter marriage appeared in two volumes authored by Gerstel and Gross (1984) and Winfield (1985). Both books synthesized widely disparate popular and academic literature, reflecting marital changes since the 1960s. Movement toward gender equality, the affirmation of individual aspirations, a distancing from traditional family forms, and changes in the nature of work, encouraged a rethinking of how couples and families might recast commitments to work and family. Commuter marriage then fit with other forms of 
experimentation in what was perceived as the dawn of a new age augmented by the dissemination of new technologies which made new ways of organizing work and relationships possible.

The literature on commuter marriage suggests that while commuting may work for some families, changing the fundamental ways in which marital relationships and family life are organized is for most families difficult, exacting an immense toll in stress, anxiety, and the quality of relationships (Kirschner \& Walum, 1978; Kiefer, 2000). The financial costs of routine communication, travel and maintaining two households may also be substantial (Weisser, 2006). Still, economics and self-fulfillment may be factors that may incline families toward considering commuter marriage.

Research on commuter marriage suggests that the emergence of a global economy increasingly impervious to time and distance encourages the structuring of family and working lives with greater fluidity. Outsourcing and downsizing are integral economic phenomenon. Employers are relying on fewer employees while achieving greater productivity from the work force by increasing overtime for hourly workers and raising expectations for salaried employees (Clarksberg \& Moen, 1998). Data from the National Study of the Changing Workforce indicate that both paid and unpaid hours at all jobs have risen from 43.6 hours weekly in 1977 to 47.1 hours in 1997; an increase from 47.1 to 49.9 hours per week for men and from 39 to 44 hours per week for women (Gilbert, 2002). The erosion of leisure time, more pronounced for women, appears to depend on occupational demands, gender orientation, and life stage of the couple and family (Moen \& Sweet, 2003).

In the face of these developments, political and institutional responses remain cautious about changing worker needs and range from flex-time, job sharing and on-site child care, to unpaid leaves. The affirmation of traditional values with dubious claims to historical precedent is another response (Coontz, 2005). The increased time devoted to work signals a shift in social and family life, forcing workers to put their jobs ahead of interpersonal 
relations and families (Elkind, 1995). Like employers, dual-income families are outsourcing various facets of family life, notably to local school systems that offer meal, academic, and recreational programs both before and after school, in addition to household maintenance. Remaining child-centered is a daunting task for dual career families, especially when expectations for children's achievements begins to parallel those of adults (Lareau, 2003.) In a social environment ambivalent about children, and oriented toward work, career, and consumerism, building strong families requires both commitment and conscious effort.

\section{Dual Income Families: Work and Careers}

Couples are increasingly faced with deciding whose career takes precedence as well as weighing the disruptive social and professional costs of relocation to children and trailing spouse (Bielby \& Beilby, 1992; Stroh, 1999). The Employee Relocation Council (ERC, 2000), an organization with a largely corporate membership, has found employee and family resistance to relocation to focus increasingly on women's appraisal of their careers. In 2000, ERC reported that the number of member companies offering relocation incentive programs grew from twenty- four percent in 1990 to forty-eight percent in $2000 \mathrm{ERC}$ (2001a, 2001b). Member companies offered incentives ranging from paying fees for job placement and printing resumes to school locating, elder-care, and tax liability counseling. Despite the high cost of providing relocation benefits, more companies are being forced to offer them to retain workers. One estimate is that as many as seven percent of corporate relocations may result in commuter marriages (Moen \& Roehling, 2005).

\section{Factors Influencing the Decision to Commute}

The basic factors encouraging couples and families to consider commuter marriage are: 1) financial need or crisis; 2) professional imperative; and 3) recognition of potential 
opportunity, for example, further development of individual human capital or improved standard of living (Rotter, Barnett, \& Fawcett, 1998). Families, especially with younger children, will not typically involve themselves in commuter marriages based solely on professional imperative or opportunity.

Income is an important factor. Chronic income limitations may require settling for less to remain in the same occupation or geographic location. As Becker and Moen (1999) suggest, scaling back career, lifestyle, and income expectations, may work for some families but these trade-offs are in effect an acquiescence to downward mobility with potential implications for children's subsequent educational paths. Parental education, often a predictor of children's educational attainment, may not be sufficient to overcome broadening income gaps and an opportunity structure that increasingly favors affluent subsets in a globalizing economy.

In his extensive writing on American social structure Watkins, $(1993,1999)$ posits that the psychological need of middle class individuals for professional work may also force a rethinking of employment options. Contemporary professionals are encouraged to be entrepreneurial in matching their skills with technological innovation and careers paths, a spin-off of selfefficacy, especially in tight job markets or for those with specialized skills. With significant financial and emotional investments in developing career skills, a professional persona, and selective consumer tastes, the effect of not working professionally can be complex and profound.

Perception of opportunity may also encourage experimentation with commuting. Being stuck on a career ladder, e.g., at a skill, responsibility or opportunity level, may make commuting attractive. However, assessing the presumed benefits of commuting can only be tentative. A detailed appraisal of commuting may have to wait until the actual experience is weighed against its costs. How families and couples weigh cost against opportunity is of substantial importance but has received little systematic attention in the literature.

As a first step, families considering commuting should 
make a detailed inventory of their strengths and weaknesses and the pressures they are likely to face. Getting an informed and objective assessment of what the family is likely to encounter is an important second step. Working through potential commuting scenarios with a family practice counselor or therapist offers an excellent way of identifying family strengths, goals, potential stresses and conflicts, as well as unarticulated issues. Families tend to underestimate the rough ride they are designing for themselves and its potential long term consequences. Minor issues may become major ones under unforeseen circumstances and may threaten family relationships and stability, as well as family goals. Gaining an informed assessment of what commuting might realistically entail for one's family before making career or family changes is a worthwhile investment of time and resources.

Successful commuter marriages require both preconditions and continual adjustments. Put in terms of family strengths, the authors' interviews with commuters suggest the minimal underpinnings for a successful commuter marriage is a stable egalitarian relationship with open family-wide communication and agreement on the goals and parameters of commuting. Other important strengths are flexibility in family roles and the ability to grow with and through one's children. Love for one's children and their well-being and future often serves as an inner thermostat regulating the emotional climate for family members and the commuting spouse in particular.

Marriages of shorter duration, or adjusting marriages in Gross's (1980) terminology, find spouses experiencing more difficulty with separation than established marriages, especially those in which children are grown. In adjusting marriages, commitments, traditions, full-assurance in the success and health of the marriage may not yet be fully established; commuting compounds these issues. The heart of the matter for all commuting couples and families involves separation; how difficult is it for spouses and children to be separated from one another? The cost, experienced as loneliness, frustration and anxiety, may be debilitating for both children and adults. 
Despite Coontz's (2005) contention that (traditional) marriage has lost its privileged legal and cultural position in North America, being separated from one's spouse, children, and household, by choice puts the commuter on the far edge of conventionality. Writing from a business perspective, Bern (1999) notes that although employers on the whole benefit from the flexibility of commuter marriage, individual employers sometimes interpret commuting as a "marriage in trouble", lacking conventional stability and negatively effecting job performance. Employers must also consider whether commuting employees will be more likely to quit jobs than will relocated employees. Stroh (1999) suggests insufficient research has been done on employer attitudes toward commuting but notes that the probable success of commuting couples is enhanced by increased age, length of marriage, established careers and the absence of child-rearing responsibilities.

In the remainder of this article the authors illustrate how relying on basic family strengths while encouraging and nurturing others has helped in the experience of commuting. The authors' intention is not to set themselves above the social and economic trends described here but rather to illustrate how individuals and families can navigate through them if they are considering commuting. An overview of methodological issues (Appendix I) provides readers with concepts important for judging the strengths and limitations of the narratives offered here.

\section{Two Case Studies in Commuter Marriage}

\section{Anne's Story}

Anne's commuting began in 1989 after twenty-six years of marriage to an attorney in which they had raised three children now aged 24, 21, and 14. A tenured university professor in Curriculum and Instruction in 1989, she followed a traditional division of responsibility in her marriage, leaving Anne to make accommodations between child rearing and career, including teaching four nights a week. Like the urban peasant Arlie 
Hochschild (1997) likens to contemporary women, Anne ran the family household, put in school appearances, managed after school enrichment activities, entertained her husband's clients and competed for tenure against career oriented male colleagues. Nested in sound, happy family life, Anne did not feel her family viewed her as a traditional spouse and parent.

Anne's was a strong family with members supportive of one another, and enjoyed each other's company. Individual growth and achievement were valued, and family members took pride in one another's accomplishments and were cognizant of individual family members' problems and needs. Anne's personal growth, coinciding with a time of greater reflectivity among women, came into tension with routines and expectations within the family. Having completed the most labor intensive period of child rearing and in a stable, happy marriage, Anne considered renegotiating her obligations within the family. Expectations turned out to be more traditional than Anne initially thought. Accommodation had papered over points of strain.

When an attractive faculty position became available in another part of the Midwest, Anne considered applying. This opportunity carried a higher level of responsibility, permitting a fuller use of her talents, including administrative skills, and a significantly higher salary. Several interviews placed career change and logistical issues on the forefront of the family agenda. The new job was discussed with the children, one of who was already living independently, and with Anne's husband. While the (nearly grown) children provided "obligatory support," they were deeply ambivalent about what this new situation meant for them and the family collectively. In this instance, a therapist or counselor might well have been able to recognize these feelings and bring them out for discussion. Instead they festered. Relocation for Anne's husband was not a realistic possibility.

Anne found much of the personal freedom attributed to the commuter marriage life style illusory. Adapting to commuting is difficult. Psychologically, commuter spouses do not relinquish the stresses and worries associated with home and household 
maintenance. Concerns about job performance, physical stresses and emotional wear and tear are also issues. Commuting calls on inner resources and the ability to reach out to others for support and assistance, more difficult for men than women in our society. Being separated from family, community and friends brings on significant loneliness. Making effective use of time is an important skill acquired by trial and error. Both authors agree that separating leisure and work is essential, since there is a natural inclination, at least initially, to fill down time with work.

Even with social support, Anne found working through the culturally laden assumptions of how married people with children should live very difficult. Commuter marriages conjure up public doubts about commitment to one's spouse, children, and family. Anne, like many commuting women, has had to work through guilt about being away from her spouse and children, as well as contending with the raised eyebrows of co-workers, extended family and friends. Having a clear set of shared goals and being able to ask for assurance are essential for commuter marriages to work. Reassurance translates into significant phone bills (a fixed cost of commuting) although E-mail facilitates some types of routine communication.

In Anne's experience, regularly scheduled trips home were essential for maintaining strong family ties, especially when children are involved. Set schedules should be kept to insure continuity in family life and reassurance to children. Activities should center on the family, and it is a good idea, especially for shorter visits, to bring as little work home as possible. In time, commuters often feel as though they live in two worlds, and reentry and exiting is difficult and a little disorienting.

Anne's decision in 1994 to leave her position in the Midwest for a new one on the East Coast was brought on by family crisis. Costs of rehabilitation and retraining for an (adult) child's closed-head injury prompted movement into a higher level administrative post enabling the family to meet unprecedented financial needs. In this time of crisis, unity and support for this family member emerged as an important strength in Anne's family. 
This second round of commuting lasted six years. Unanticipated opportunities in administration emerged during this period leading to an academic vice presidency.

Meeting this crisis forced family members to reinterpret Anne's commuting. Her ability to make substantial financial contributions to a critical family undertaking and her professional success were recognized. With a significantly higher level of responsibility commuting became two-way, with Anne's husband (and curious adult-children) making occasional visits. These visits were indicative of personal support and open communication but not of commuting itself; anger and criticism was sometimes part of the visitation package. One of Anne's children has been in therapy and her commuting has been an issue.

Anne's commuting continued with her acceptance of a campus presidency in the Midwest, a half-day commute from the family's home, in 1999. Her husband began visiting weekends and joined the state bar association as he explored extending his practice to her community. This period of apparent resolution in Anne's family was shattered with her husband's unanticipated death. Anne's ensuing personal crisis involved not only the process of mourning but the necessity of rethinking her life plan and path after retirement. (She has subsequently accepted another presidency in a small private college.) Having weathered more than a decade of parental commuting, this unanticipated tragedy is a bitter irony for the three grown children.

Asked if she would do it again, Anne's response is, "I had no choice." Professional growth and opportunity were certainly important to her, but financial issues at all stages were the deciding factor. Her opinion of commuter marriage remains that it is workable but it is essential that families pull together at all costs. From Anne's perspective, loyalty and cooperation are long term family strengths essential for commuter marriages. In Anne's case, the age of the children obscures the effects of commuter marriage on young children but surely suggests possible negative effects for adolescents and young adults. 
Rich's Story

Anne's move to the East Coast enabled her to resolve some aspects of a family crisis. As a faculty member at the same institution, recently married with two small children, Rich considered that salary and career might be better met at another institution. The authors" friendship and "plan" to work on a research project together, dates from this period.

The dynamics and focus of Rich's adult life centered on varied work, travel, and graduate school experiences. Marrying late, Rich became a father at 41 and again at 44. Marrying a younger spouse, the early part of Rich's marriage was spent divided between his career development and her return to the university to complete an undergraduate degree. A shared world view and some parallel life experiences provided a foundation for developing such basic family strengths as open communication, mutual respect, support and encouragement, and providing for each others' emotional and spiritual needs. Having children fulfilled an important part of their life plan but pointed toward future sources of strain because of limited financial resources. Both spouses worked full-time and both children went into preschool at eight weeks and one year respectively. Indeed, one of the attractive features of this college town was its outstanding campus preschool.

The costs of maintaining a first home, the expense of fulltime preschool for two children, a chronically poor local economy and unsettled times with the university system, prompted Rich to reenter the job market after 13 years. Both spouses shared recognition of economic issues, dramatized by an unanticipated stint of unemployment for Rich's wife. Extended family was important to Rich's spouse. The family gave the prospect of relocation a lukewarm reception. In retrospect, Rich's pattern of career development was traditionalist, paying less than full attention to his wife's hesitations and geographical locales. Rich's focus was on avoiding being "trapped" at mid-career, conveniently assuming that his wife's career prospects were more important than her closeness to family. 
A job search brought an opportunity to combine scholarly work with administration in an offer from the Midwest in 1997. Although a high degree of egalitarianism had developed between spouses, there was less than full agreement on this move. The trailing spouse and children, now aged 3 and 6 , were entering a world far different than what they were accustomed to without the anchors of work, school, friends, or family. As Anne Hendershott (1995) suggests in her relocation research, a place-specific litany of complaints is less useful for analysis than is focusing on major change as a source of stress, taxing the adaptability of families and individuals. In his former institution Rich had listened incredulously as new faculty made the same complaints his family would later make to equally incredulous Midwestern colleagues and neighbors.

During their first year settling in was difficult and made more so by the onset of illness of her aging parents. The disparity between spousal routines spilled over into ongoing arguments and anxieties. Lack of acceptable child-care keep Rich's wife out of the work force and brought the family to a point of crisis. With emotional and financial resources severely taxed, they wondered whether the marriage itself was threatened. Commuting emerged as an option because the family home had been rented rather than sold and Rich felt ethically bound to complete a series of tasks outlined for new colleagues.

Rich and his wife had several commuter models to examine. Anne's marriage was one, and another was of friends in New England, whose long-term commuting had no apparent ill effects on their two children. Several former colleagues were also commuters, and Rich subsequently met a number of long distance commuters on his new campus. Commuting became an emotionally risky but viable option by the end of the family's first year in the Midwest.

Divorce has become a common part of the American social landscape, and children are increasingly sensitized to disruptive change or tension within a family. Their older child began asking peers at school about divorce. These inquiries came home as 
surprisingly well-informed bedtime questions about the state of the family, painful for both parents. The big question, "Are you and mom getting reversed?" prompted serious work on a solution. In Anne's home the initial decision to commute had prompted one of their children to break into tears at the breakfast table and announce a parental divorce in all of its details including future living arrangements. Divorce emerged as a topic at several points of high tension with spouses for both Anne and Rich. However following divorce to its logical conclusions created far more problems than it purported to solve. The end of Rich's family's Midwest experience marked the beginning of a four-and-a-halfyear commuting experiment for Rich.

For Rich, time proved both friend and adversary. Having always wanted large blocks of time for research and writing, Rich made good use of time but found surplus time or "leisure," difficult. Being away from one's children when they are making great developmental strides is frustrating. Reorganizing family finances to accommodate the realities of a family home and minihousehold are tricky, requiring some departure from the usual family pattern of pooling resources. Funneling the majority of one's income "home" provides both a sense of satisfaction and frustration in living on a limited budget in which travel and the need to plan for it, consume a significant percentage of resources.

Rich quickly found that the most important aspect of commuting for children is regularity and predictability in parental visits. Children should know arrival dates, have assurances of individual time with the parent, and have information about the departure and the next visit. Avoiding the Santa Claus Syndrome, or bringing expensive gifts, is important since the anticipation of gifts shifts the focus from the affective to the material. Rich found opportunities to search out creative and thoughtful gifts related to school projects and children's interests. Stockpiling off-season sale items is another useful option. Regular communication is equally important.

Telephone, e-mail and letter writing are all important for commuters. Rich's children were supplied with self-addressed 
stamped envelopes when they were young; the rule was to write or send pictures when you want but never because you have to. Writing became an enjoyable, if sporadic, activity and one both children took pride in. As teens writing has been superseded by email. School web sites provide a means for Rich to stay informed about school activities, homework and class projects. Rich has collaborated on a number of school projects with both children, contributing learning materials, science equipment and ideas, with his wife providing the hands-on assistance at home. Rich's wife has also seen to the children's religious education, which both parents believe have become important strengths for the family.

Four and a half years of commuting brought a workable routine. Tension between spouses subsided but periodically reemerged in the frustration over distance and household maintenance. Finding a balance between work, leisure, and down time, has been sometimes problematic. Rich's family believes, as does he, that there should be a time limit on commuting. Both children accept their father's commuting as a stage in the family's development but do not accept it as a permanent lifestyle. (Both children, now in middle school and high school high respectively, have been lucky in finding schoolmates with commuter parents.)

While the children have been told that this arrangement is not permanent, Rich's search for a geographically closer job has not brought him home. Accepting a new position in a large state university represents upward occupational mobility with accompanying professional opportunities and financial incentives. Substantially closer to home, weekend visits are easily achieved. Both children are pleased with the move but disappointed that it does not represent a return to the family home except during weekends, holidays and summers. Both children have visited Rich's new environment, expressing satisfaction with his apartment and work situation. Visits give both children a clearer picture of how their father lives when he is away and what his job entails. While this move may prove temporary, the issue of financing the children's college education and the university's generous tuition plan are becoming increasing important. 
As the children have moved into their teens commuting has brought an interesting, albeit disquieting development; Rich's commuting is now blamed for a variety of social ills ranging from the occasional problematic grade to mother-daughter conflict, and a marginally acceptable boyfriend. Infractions of household rules and late hours are sometimes blamed on the absence of a parent or "father figure." While some of this is sophisticated excuse making, it suggests that there is an underlying issue with Rich's weekday absence for so many years that must be brought out into the open. What Rich perceives as his sacrifices do not alter the reality of his children's feelings.

Rich also believes that he had little choice but to experiment with commuting. Change was essential to meet important long-term family and personal goals. Increased earnings funded pre-school and currently support a range of enriching activities in addition to unanticipated orthodontia. From a career development standpoint, Rich has gained a great deal translating the commuting into advantages for himself and the family. Rich's wife has turned her situation to advantage, forming a network of friends centered on the children's education and her own career development. Now that the children are older and less dependent in an immediate sense, full-time employment again became possible. Managing a household, children, and the beginnings of a promising full-time career (secured through her network), has brought the marriage to a more genuinely egalitarian footing.

\section{Family Strengths and Commuter Marriage: Some Observations}

Many couples, particularly in business and academia, are finding that the dynamics and preferences of their personal lives are being challenged by the demands and logistics of work. As Coontz (2005) writes; “The big problem doesn't lie in differences between what men and women want out of life and love. The big problem is how hard it is to achieve equal relationships in a society whose work policies, school schedules, and societal programs were 
constructed on the assumption that male breadwinner families would always be the norm" (p.300). It is ironic that the shared interests, goals, and ambitions that draw couples together during courtship may later prove to be contentious within marriages, especially where children and parenting are involved. Early on, dual career couples should decide whose career will take precedence, for how long, and which partner must risk settling for less than they might achieve otherwise. Commuting may, under some circumstances, provide a means of avoiding an impasse without sacrificing the stability and quality of one's marriage. For adults, efficient planning and time use, learning to live with ambiguity, and being reliable are essential characteristics that can help couples and families with commuting. Commuter marriage does not signal an abdication of child rearing responsibilities for the commuter spouse. Instead, commuting requires a thoughtful and continuously evolving reconfiguration of active parenting.

Commitment to family life is the single most important aspect of commuting. There are many ways to be a thoughtful and participatory spouse and a loving parent, ranging from varying one's modes of communication, creating photo albums for children of one's residence, workplace, and community environment, and arranging visits to giving unique gifts related to the children's school or extracurricular interests. Supplying younger children with pre-addressed stamped envelopes also helps keep communication two-way. Set schedules and information about visits and special time with the commuter parent are very important for establishing a predictable environment for children with some flexibility built in. While commuter families must be flexible, excessive and continuous ambiguity within the family about scheduling, visits, and the parameters of commuting makes children anxious.

Flexibility is both an approach to life and a means of situation-specific problem solving. Families should at very least make a detailed inventory of their strengths and weaknesses, and what they anticipate facing as a commuter family. Families owe it to themselves to work through the commuting scenario with a 
family practice counselor or therapist to clarify the feasibility of commuting and its potential costs and benefits to the family. The more arduous and complex the commute, the more important sound planning becomes.

Both authors' families have fared reasonably well to date in this period of transition and change. The two families presented resolved to remain child-centered despite the voluntary absence of a parent. That both authors grew up in that ambiguous space between working class and middle class life has informed their aspirations and apprehensions. While recognizing the limitations of the existing opportunity structure, understanding its unique character and prospects has been helpful. Commuting has proved an effective means of bettering the lot of loved ones although not without substantial costs.

\section{Narrative Experience}

Narration, or the telling of life stories, helps makes sense of individual experience, especially in initial recollection when chronology, sequencing, and the presence of others, must be sorted out from the irrelevant. What remains as central to one's experience then becomes subject to the process of continuous reinterpretation, taking into account such factors as prior and subsequent experience, insight and consciousness of audience (Lieblich et al., 1998). Three basic problems emerge in how experience is recalled and narrated; selective recall, reexamination and reinterpretation, and filling-in gaps of memory with inference (Ross \& Conway, 1986). Painful or embarrassing experiences tend to get revised first (Norrick, 1997).

Sharing draft accounts of commuting experiences with family members and fellow commuters provided fresh insights but also brought to the fore the authors' proclivity for reworking the more contentious aspects of their experiences. The respective families had quite a different take on some aspects of commuting as did colleagues when they were asked to read and critique our accounts. Under this regimen the sanguine recounting of many 
events was challenged resulting in a reworking of the initial defensive and self-justifying tones of our narratives.

Developmental and communicative changes have become part of our respective family's reexamination and reinterpretation of commuting. Normal developmental processes brought on by maturing, increasingly independent children, longevity of marriage, and predictability of family life, account for some of this change, but commuting itself accounts for other aspects of change. Van Langenhove and Harré (1993) draw a useful distinction between the flexible and permeable core of "self," continuous across the life span, and the "social self," which relies on interactive agency and efficacy, in the interpretation and meaning attached to experiences and events in a social context. One can be "the same" and yet appear in many guises or transformations across the life span. Both authors believe that commuting has changed them. New places, people, and workplace challenges added experience, resilience and a better-albeit imperfectcapacity to solve problems. Both authors consider themselves more self-contained and independent than previously while still remaining like their rather gregarious "old selves."

\section{References}

Becker, P., \& Moen, P. (1999). Scaling back: Dual-earner couples' work-family strategies. Journal of Marriage and Family, 61, 995-1007.

Beilby, W. T., \& Beilby, D. (1992). I will follow him: Family ties, gender-role beliefs, and reluctance to relocate for a better job. American Journal of Sociology, 5, 1241-67.

Bern, P. (1999). Little big man...Commuter marriages...Mega-job perks. Milwaukee Journal Sentinel. Retrieved September 20, 2007,from 
http://www.jsonline.com/bym/career/feb00berncol27020900a.a sp.

Bond, J., Galinsky, E., \& Swanberg, J. (1997). The 1997 national study of the changing workforce. New York: Families and Work Institute.

Bulcroft, R., Bulcroft, K., Bradley, K., \& Simpson, C. (2000). The management and production of risk in romantic relationships: A postmodern paradox. Journal of Family History, 25, 63-92.

Bunker, B. B., Zubeck, J. M., \& Vanderslice, V. J. (1992). Quality of life in dual-career families: Commuting versus singleresidence couples. Journal of Marriage and Family, 54, 399407.

Clarksberg, M., \& Moen, P. (1998). Bronfenbrenner Life Course Center Working Papers. Working families in transition: Husbands' and wives' hours on the job. Ithaca, NY: Cornell University Press.

Coontz, S. (2005). Marriage, a history: How love conquered marriage. New York: Viking Press.

Eby, L., Allen, T., \& Douthitt, S. (1999). The role of nonperformance factors on job related relocation opportunities: A field study and laboratory experiment. Organized Behavior and Human Decision Processes, 79(1), 29-55.

Elkind, D. (1995). Ties that stress: The new family imbalance. Cambridge, MA: Harvard University Press.

Employee Relocation Council. (2000). Family Issues Survey. Washington, DC: ERC. 
Employee Relocation Council. (2001a). Transfer Volume and Cost Survey. Washington, DC: ERC.

Employee Relocation Council. (2001b). Family Issues Survey. Washington DC: ERC.

Franklin, J., \& Ramage, M. (1999). Till a long distance job do us part: Commuter marriages. Kiplinger's Personal Finance Magazine. Retrieved October 11, 2007, from http://findarticles.com/p/articles/mi_m1318/is_1_53/ai_534090 $\underline{47}$.

Gerstal, N., \& Gross, H. (1984). Commuter marriage: a study of work and family. New York: Guilford Press.

Gilbert, A. (2002). Facilitating or resisting: Patterns of satisfaction and spousal attitudes in the family life of highly educated workers. Working Paper 14. Berkeley, CA: Center for Working Families, University of California.

Gross, H. E. (1980). Dual career couples who live apart: Two types. Journal of Marriage and Family, 43, 567-576.

Groves, M., \& Horm-Wingerd, D. M. (1991). Commuter marriages: personal, family and career issues. Sociology and Social Research, 75, 212-217.

Hendershott, A. B. (1995). Moving for work. The sociology of relocating in the 1990s. Boston: University Press of America.

Hochschild, A. (1997). The time bind: When work becomes home and home becomes work. New York: Metropolitan Books.

Jackson, A. P., Brown, R. P., \& Patterson-Stewart, K. E. (2000). African-Americans in dual-career commuter marriages: An 
investigation of their experiences. The Family Journal, 8, 2236.

Kiefer, F. (2000). Commuter marriages test more Americans. Christian Science Monitor, 92, 1.

Kirschner, B., \& Walum, L. (1978). Two-location families: Married singles. Alternative Lifestyles, 1, 513-525.

Lareau, A. (2003). Unequal childhoods: Class race and family life. Berkeley, CA: University of California Press.

Leiblich, A., Tuval-Mashiach, R., \& Zilber, T. (1998). Narrative research: Reading, analysis, and interpretation. Thousand Oaks, CA: Sage.

McCubbin, H. I., Thompson, A. I., \& McCubbin, M. A. (1996). Family assessment: Resiliency, coping, and adaptation. Madison, WI: University of Wisconsin Press.

Moen, P., \& Roehling, P. (2005). The career mystique. Lanham, MD: Rowman and Littlefield.

Norrick, N. R. (1997). Twice-told tales: Collaborative narration of family stories. Language in Society, 26, 199-220.

Olsen, D., \& DeFrain, J. (1994). Marriage and family: Diversity and strengths. Mountain View, CA: Sage.

Otto, H.A. (1962). What is a strong family? Marriage and Family Living, 24, 77-81.

Otto, H.A. (1963). Criteria for assessing family strengths. Family Process, 2, 329-334.

Ross, M., \& Conway, M. (1986). Remembering one's own past: 
The construction of personal histories. In R. Sorrentino \& E. Higgins (Eds.), Handbook of motivation and cognition (pp.122144). New York: Guildford Press.

Rotter, J. C., Barnett, D. E., \& Fawcett, M. L. (1998). On the road again: Dual-career commuter relationships. Family Journal 6, 46-48.

Schnittger, M., \& Bird, G. (1990). Coping among dual career men and women across the family life cycle. Family Relations, 39, 199-205.

Stinnett, N., \& DeFrain, J. (1985). Secrets of strong families. Boston: Little, Brown and Company.

Stroh, L. K. (1999). Does relocation still benefit corporations and employees? An overview of the literature. Human Resource Management, 9, 279-304.

Tolbert, P. S., \& Moen, P. (1998). Men's and women's definitions of 'good jobs': similarities and differences by age and across time. Work and Occupations, 25, 168-94.

Van Langenhove, L., \& Harré, R. (1993). Positioning and autobiography: Telling your life. In N. Coupland \& J. Nussbaum (Eds.), Discourse and lifespan identity (pp. 81-100). Newbury Park, CA: Sage.

Watkins, E. (1993). Throwaways: Work culture and consumer education. Palo Alto, CA: Stanford University Press.

Watkins, E. (1999). Everyday exchanges: Marketwork and capitalist common sense. Palo Alto, CA: Stanford University Press. 
Miles that Bind 31

Weisser, C. (2006). Two cities, two careers: Too much? Money. Retrieved October 11, 2007, from http://money.cnn.com/magazines/moneymag/moneymag_archi ve/2006/01/01/8365210/index.htm.

Winfield, F. E. (1985). Commuter marriage: Living together, apart. New York: Columbia University Press. 